\title{
GIANT SIZED EXTRAVESICAL BLADDER LEIOMYOMA MIMICKING UTERINE CERVICAL LEIOMYOMA: A CASE REPORT WITH 8 YEARS' POSTOPERATIVE FOLLOW-UP AND A REVIEW OF THE LITERATURE
}

\author{
UTERIN SERVIKAL LEIOMYOMU TAKLIT EDEN DEV EKSTRAVEZIKAL MESANE \\ LEIOMYOMU: 8 YILLIK POSTOPERATIF TAKIBI VE LITERATÜRÜN GÖZDEN GEÇIRILMESI
}

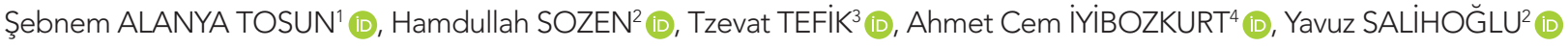 \\ ${ }^{1}$ Giresun University, Faculty of Medicine, Department of Gynecology and Obstetrics, Giresun, Turkey \\ ${ }^{2}$ Istanbul University, Istanbul Faculty of Medicine, Department of Gynecology and Obstetrics, Division of Gynecologic Oncology, \\ Istanbul, Turkey \\ ${ }^{3}$ Istanbul University, Istanbul Faculty of Medicine, Department of Urology, Istanbul, Turkey \\ ${ }^{4}$ Demiroglu Bilim University, Department of Gynecology and Obstetrics, Istanbul, Turkey
}

ORCID IDs of the authors: Ş.A.T. 0000-0002-2044-1044; H.S. 0000-0002-0568-5307; T.T. 0000-0002-1398-8332; A.C.I. 0000-0002-5047-2191; Y.S. 0000-0002-8058-5568

Cite this article as: Alanya Tosun S, Sozen H, Tefik T, lyibozkurt AC, Salihoglu Y. Giant sized extravesical bladder leiomyoma mimicking uterine cervical leiomyoma: a case report with 8 years' postoperative follow-up and a review of the literature. J Ist Faculty Med 2021;84(3):448-53. doi: 10.26650/IUITFD.2021.804321

\begin{abstract}
The incidence of bladder leiomyoma is estimated at only $0.43 \%$ because most bladder tumors arise from the urothelium. Moreover, $30 \%$ of them are the extra-vesical type. The symptoms include urinary tract obstruction, bladder irritation, and dysuria, with the possibility of dyspareunia or hematuria depending on the size and location of the tumor. Bladder leiomyomas cannot be diagnosed solely by combining symptoms and imaging techniques. We present a rare case of giant sized extravesical-type bladder leiomyoma with a diameter of $15.5 \times 14.5 \times 14 \mathrm{~cm}$, which was misdiagnosed as a uterine cervical leiomyoma. It caused unilateral ureteral distension without related symptoms. During the 8-year postoperative follow-up, the patient had two healthy full-term pregnancies and no recurrence was observed. We reviewed the literature of the most recent five years and discussed the characteristics of 22 bladder leiomyoma cases. Unlike the literature, the present case is unique due to the giant size of the bladder leiomyoma, its ureteral complications, and long follow-up period. Bladder leiomyomas are rare bladder tumors which should be borne in mind during the differential diagnosis of a pelvic mass. Surgical excision is the most useful procedure for diagnosis and treatment.
\end{abstract}

Keywords: Bladder leiomyoma, bladder tumor, cervical leiomyoma, cervical tumor, differential diagnosis

\begin{abstract}
ÖZET
Mesane leiomyomunun insidansı sadece \%0,43 olarak tahmin edilmektedir; çünkü mesane tümörlerinin çoğu üroepitelyumdan kaynaklanmaktadır. Bunun yanı sıra, mesane leiomyomlarının sadece \%30'u ekstra-vezikal tiptedir. Üriner sistem obstrüksiyonu, mesane irritasyonu, dizüri, disparoni veya hematüri gibi semptomlar kitlenin boyut ve yerine göre değişebilir. Yalnızca semptom ve görüntüleme tekniklerine dayanarak mesane leiomyomu tanısı konulamayabilmektedir. Preoperatif uterin servikal leiomyom ön tanısı düşünülen, $15,5 \times 14,5 \times 14 \mathrm{~cm}$ çapında tek taraflı üreteral distansiyona yol açan, nadir görülen bir ekstravezikal tip mesane leiomyomu olgusunu sunuyoruz. Sekiz yıllık postoperatif takip boyunca, hastanın iki sağlıklı term gebeliği mevcuttu ve nüks izlenmedi. Son beş yılın literatürü gözden geçirilerek 22 mesane leiomyomunun özellikleri sunuldu. Literatürden farklı olarak, mevcut olgu mesane leiomyomunun büyüklüğü, üreteral komplikasyonları ve uzun takip süresi ile benzersizdir. Mesane leiomyomları, pelvik kitlenin ayırıcı tanısında göz önünde tutulması gereken, nadir görülen mesane tümörleridir. Tanı ve tedavi için en faydalı prosedür cerrahi eksizyondur.
\end{abstract}

Anahtar Kelimeler: Mesane leiomyomu, mesane tümörü, servikal leiomyom, servikal tümör, ayırıcı tanı

Corresponding author/iletişim kurulacak yazar: sebnem_alanya@hotmail.com

Submitted/Başvuru: 04.10.2020 • Revision Requested/Revizyon Talebi: 01.10.2020 •

Last Revision Received/Son Revizyon: 20.11.2020 • Accepted/Kabul: 12.12.2020 • Published Online/Online Yayın: 12.07.2021 


\section{INTRODUCTION}

Bladder leiomyoma is a rarely seen mesenchymal neoplasm of the urinary bladder, and it is only estimated to occur in $0.43 \%$ of adults. Incidence of this condition is higher in female patients in their fifth decade (1). The etiology is uncertain; effects of hormones, inflammation, localized infection, and chromosomal abnormalities may play a role. The symptoms depend on the location and size of the tumor, which is categorized as endovesical, intramural or extravesical with frequencies of $63 \%, 7 \%$ and $30 \%$, respectively (2). Voiding symptoms such as hematuria, dysuria and/or obstructive symptoms are generally seen in endovesical-type tumors, whereas bladder neck obstruction due to compression of the ureter may lead to upper urinary tract obstruction and hydronephrosis in extravesical-type tumors (3). Like uterine leiomyoma, radiologic differentiation of bladder leiomyoma from leiomyosarcoma is not clearly defined.
We present a rare case of a giant extra-vesical type bladder leiomyoma, leading to unilateral ureteral distension, which was misdiagnosed as a cervical leiomyoma. We also report the 8-year follow-up and review the related literature on the last five years between 2016 and 2021.

\section{CASE REPORT}

A 23-year-old nulliparous woman was referred due to a pelvic mass with symptoms of dysuria and chronic pelvic pain. Her urologic and gynecologic histories were unremarkable. On gynecologic examination, the mass occupied the entire pelvis till $2 \mathrm{~cm}$ above the umbilicus, bulging the right vaginal wall and obliterating the vaginal lumen; the uterine cervix was unremarkable. Laboratory tests revealed normal tumor markers and urinalysis.

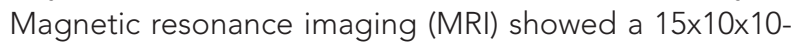
$\mathrm{cm}$ mass of low signal intensity on T2-weighted images, which appeared adjacent to the right cervical wall, compressing the right ureter and the bladder (Figure 1A, 1B).

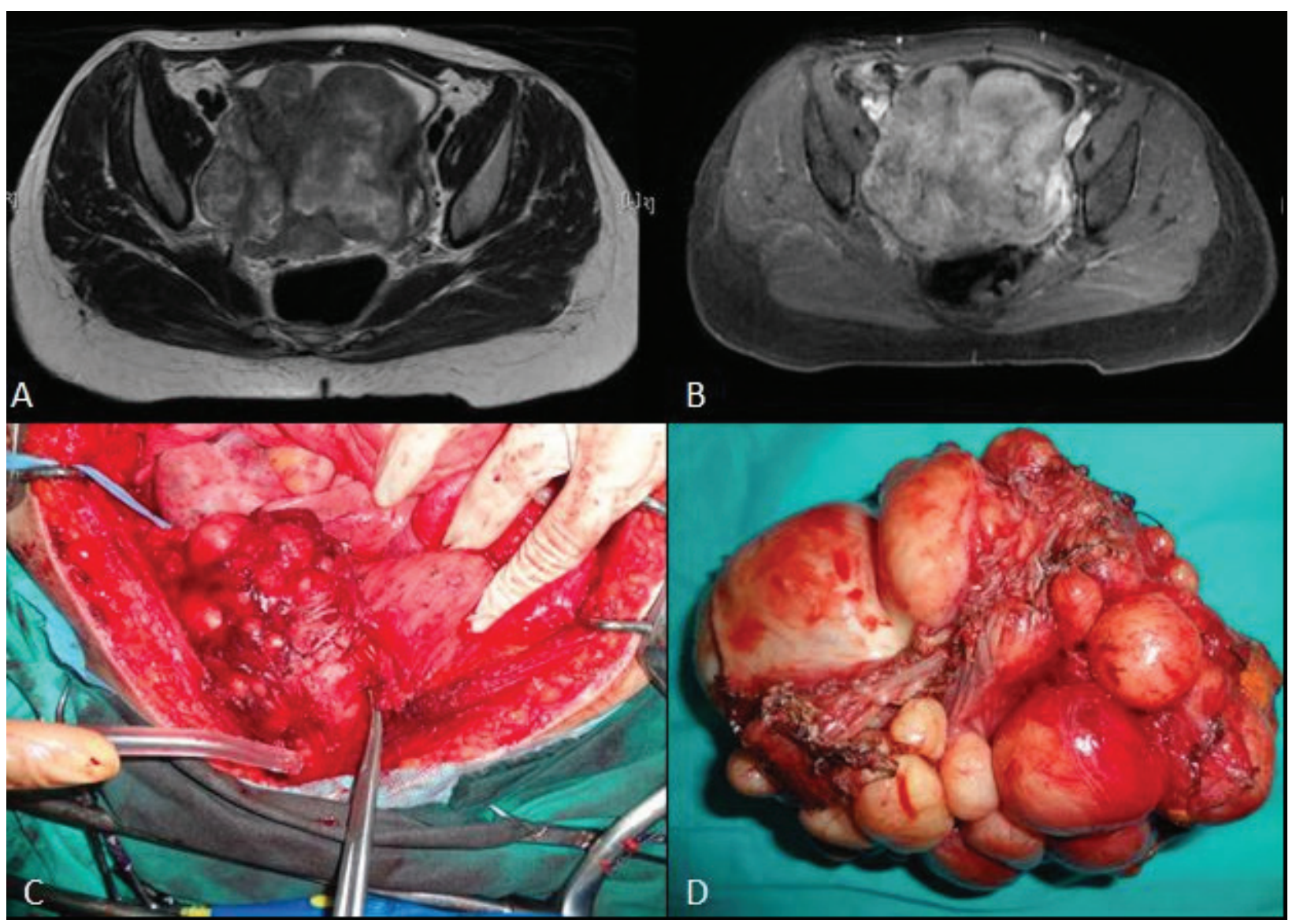

Figure 1: (A). Fat-suppressed T1-weighted sequence after intravenous gadolinium administration demonstrating a giant mass with heterogeneous contrast agent fixation that occupies the entire pelvis. (B). T2-weighted sequence showing a solid lesion with partially high signal areas and no clear border separation visible in the adjacent bladder. (C), The bladder leiomyoma reached the bladder mucosa and compressed the uterine cervix from the antero-lateral part. (D). The bladder leiomyoma was approximately $10 \times 15 \mathrm{~cm}$ in size. 
The signal intensity was similar to leiomyoma and leiomyosarcoma of the uterus on MRI. Based on the clinical and radiologic findings, the mass was estimated to be leiomyoma or leiomyosarcoma of the cervix.

Surgery was performed with a low midline incision; it was observed that the mass originated from the right side of the bladder wall and extended as far as the right parametrium (Figure 1C). Perioperatively, it was considered as $15.5 \times 14.5 \times 14 \mathrm{~cm}$ extravesical bladder leiomyoma that reached the bladder mucosa (Figure 1D). The distal part of the right ureter was passing through the mass. Pararectal, paravesical and Retzius spaces were developed. The distended right midureter was dissected and a full cut incision was performed to the bladder wall for total excision. The right distal ureter was excised and ureteroneocystostomy was performed. The bladder wall was repaired in two layers, the first consisting of mucosa using 3-0 vicryl, and the second consisting of detrusor and serosa using 2-0 vicryl sutures and a double-J catheter which was inserted through the lumen. The histopathologic investigation reported a bladder leiomyoma without cytologic atypia or necrosis. It stained positively for smooth muscle actin and vimentin, and estrogen and progesterone receptors were positive. The postoperative period was uneventful and the patient was discharged on the $6^{\text {th }}$ day after the operation without complications.

During follow-up, spontaneous pregnancy occurred two years later. During the 8-year postoperative follow-up, the patient had two healthy full-term pregnancies and delivered via an uncomplicated cesarean section. The indication for the first cesarean section was fetal macrosomia. During follow up no recurrence was observed.

\section{DISCUSSION}

Bladder leiomyoma was first described by Virchow in 1931 and there are about 250 cases in the literature (4). As recent studies have shown promise in establishing best practices for evaluation and management, we reviewed the related studies on the last five years between 2016 and 2021. To review the features of bladder leiomyoma such as symptoms, diagnosis tools, treatment and prognosis, a literature search of PubMed and the Web of Science was conducted, which included 22 cases of bladder leiomyomas in 17 publications as shown in Table 1 (1, 3-18). The symptoms vary according to the location of the

Table 1: A review of case reports reported as bladder leiomyomas in histopathologic examinations between 2016 and 2021

\begin{tabular}{|c|c|c|c|c|c|c|c|c|}
\hline Study & $\begin{array}{l}\text { Age/ } \\
\text { sex }\end{array}$ & $\begin{array}{l}\text { Symptom/ } \\
\text { history }\end{array}$ & Size & Location & $\begin{array}{l}\text { Diagnosis } \\
\text { tool }\end{array}$ & $\begin{array}{l}\text { Initial } \\
\text { diagnosis } \\
\text { before } \\
\text { surgery }\end{array}$ & Treatment & Follow-up \\
\hline $\begin{array}{l}\text { Xin et al. } \\
2016\end{array}$ & $44 / F$ & dyspareunia & $7.3 \times 6.1 \times 5.8 \mathrm{~cm}$ & $\begin{array}{l}\text { Trigone of } \\
\text { urinary bladder }\end{array}$ & USG, CT & $\begin{array}{l}\text { Soft tissue } \\
\text { mass }\end{array}$ & $\begin{array}{l}\text { Open surgical } \\
\text { excision }\end{array}$ & $\begin{array}{l}8 \text { months } \\
\text { without } \\
\text { recurrence }\end{array}$ \\
\hline $\begin{array}{l}\text { Haddad } \\
\text { et al. } \\
2016\end{array}$ & $37 / \mathrm{M}$ & $\begin{array}{l}\text { Severe dysuria, } \\
\text { urgency, } \\
\text { frequency, fever } \\
\text { and chills }\end{array}$ & $5.5 \times 4.3 \mathrm{~cm}$ & $\begin{array}{l}\text { Right } \\
\text { anterolateral } \\
\text { wall of urinary } \\
\text { bladder }\end{array}$ & USG, CT & $\begin{array}{l}\text { Febrile } \\
\text { urinary tract } \\
\text { infection }\end{array}$ & TUR-B & $\begin{array}{l}1 \text { year without } \\
\text { recurrence }\end{array}$ \\
\hline $\begin{array}{l}\text { Mendes } \\
\text { et al. } \\
2017\end{array}$ & $22 / F$ & $\begin{array}{l}\text { Pelvic discomfort, } \\
\text { dysuria, and } \\
\text { dyspareunia }\end{array}$ & $1.6 \times 1.1 \times 0.6 \mathrm{~cm}$ & $\begin{array}{l}\text { Anterior } \\
\text { bladder wall }\end{array}$ & $\begin{array}{l}\text { USG, } \\
\text { Cystoscopy and } \\
\text { biopsy }\end{array}$ & Cystitis & TUR-B & N/A \\
\hline $\begin{array}{l}\text { Jamshaid } \\
\text { et al. } \\
2017\end{array}$ & $38 / F$ & $\begin{array}{l}\text { lower urinary } \\
\text { tract symptoms } \\
\text { (straining, } \\
\text { intermittency, } \\
\text { sense of } \\
\text { incomplete } \\
\text { bladder } \\
\text { emptying and } \\
\text { increased } \\
\text { frequency of } \\
\text { urination) }\end{array}$ & $4.4 \times 4.5 \mathrm{~cm}$ & $\begin{array}{l}\text { Posterior inferior } \\
\text { surface of the } \\
\text { bladder near } \\
\text { the bladder } \\
\text { neck }\end{array}$ & $\begin{array}{l}\text { CT, } \\
\text { Cystoscopy }\end{array}$ & $\begin{array}{l}\text { Polypoidal } \\
\text { mass }\end{array}$ & TUR-B & $\begin{array}{l}\text { After } 6 \text { months, } \\
\text { urinary } \\
\text { retention } \\
\text { occurred. She } \\
\text { underwent } \\
\text { an open } \\
\text { local excision } \\
\text { as second } \\
\text { operation. } \\
\text { After } 1 \text { year } \\
\text { follow up, no } \\
\text { recurrence was } \\
\text { observed. }\end{array}$ \\
\hline $\begin{array}{l}\text { Dodia et } \\
\text { al. } 2017\end{array}$ & $35 / F$ & $\begin{array}{l}\text { Hematuria, } \\
\text { dysuria }\end{array}$ & $3.3 \times 4.3 \mathrm{~cm}$ & $\begin{array}{l}\text { Right } \\
\text { posterolateral } \\
\text { bladder wall }\end{array}$ & $\begin{array}{l}\text { USG, MRI, } \\
\text { Cystoscopy and } \\
\text { biopsy }\end{array}$ & N/A & $\begin{array}{l}\text { Open transvesical } \\
\text { enucleation }\end{array}$ & $N / A$ \\
\hline $\begin{array}{l}\text { He et al. } \\
2018\end{array}$ & $47 / F$ & Dysuria & $4 \mathrm{~cm}$ & $\begin{array}{l}\text { Right posterior } \\
\text { bladder wall }\end{array}$ & Pelvic CT & $N / A$ & $\begin{array}{l}\text { Open partial } \\
\text { cystectomy }\end{array}$ & $\begin{array}{l}8 \text { months } \\
\text { without } \\
\text { recurrence }\end{array}$ \\
\hline
\end{tabular}


Table 1: Continued

\begin{tabular}{|c|c|c|c|c|c|c|c|c|}
\hline $\begin{array}{l}\text { Sharma et } \\
\text { al. } 2018\end{array}$ & $65 / \mathrm{M}$ & $\begin{array}{l}\text { Lower urinary } \\
\text { tract symptoms }\end{array}$ & $3.8 \times 3.3 \times 2.4 \mathrm{~cm}$ & $\begin{array}{l}\text { Left } \\
\text { posterolateral } \\
\text { wall and left } \\
\text { vesico-ureteral } \\
\text { junction of the } \\
\text { bladder }\end{array}$ & $\begin{array}{l}\text { USG, } \\
\text { Contrast- } \\
\text { enhanced CT, } \\
\text { FDG PET/CT }\end{array}$ & $\begin{array}{l}\text { Favor of low- } \\
\text { grade urinary } \\
\text { bladder } \\
\text { neoplasm }\end{array}$ & TUR-B & N/A \\
\hline $\begin{array}{l}\text { Yucel et } \\
\text { al. } 2018\end{array}$ & $44 / \mathrm{M}$ & $\begin{array}{l}\text { Suprapubic pain } \\
\text { and history of } \\
\text { neurofibromatosis }\end{array}$ & $1.8 \times 2.2 \mathrm{~cm}$ & $\begin{array}{l}\text { Inferior bladder } \\
\text { wall }\end{array}$ & USG & $\mathrm{N} / \mathrm{A}$ & TUR-B & $\begin{array}{l}\text { After } 3 \text { months, } \\
\text { grade } 3 \\
\text { hydrouretero- } \\
\text { nephrosis on } \\
\text { left side and } \\
6 \times 3.5 \mathrm{~cm} \\
\text { mesenchymal } \\
\text { tumor from } \\
\text { the left } \\
\text { anterolateral } \\
\text { wall of the } \\
\text { bladder. }\end{array}$ \\
\hline $\begin{array}{l}\text { Pramod } \\
\text { et al. } \\
2020\end{array}$ & $42 / F$ & $\begin{array}{l}\text { Painless } \\
\text { hematuria } \\
\text { and irritative } \\
\text { symptoms }\end{array}$ & $7 \times 6.5 \times 4 \mathrm{~cm}$ & $\begin{array}{l}\text { Posteroinferior } \\
\text { wall of the } \\
\text { bladder }\end{array}$ & $\begin{array}{l}\text { USG, Doppler, } \\
\text { CT, } \\
\text { Cystoscopy }\end{array}$ & $\begin{array}{l}\text { Soft tissue } \\
\text { mass }\end{array}$ & $\begin{array}{l}\text { Open transvesical } \\
\text { excision of the } \\
\text { bladder mass }\end{array}$ & N/A \\
\hline $\begin{array}{l}\text { Sodo et } \\
\text { al. } 2019\end{array}$ & $33 / \mathrm{M}$ & $\begin{array}{l}\text { Pelvic pain, } \\
\text { urgency, dysuria }\end{array}$ & $6 \times 5.8 \times 4.7 \mathrm{~cm}$ & $\begin{array}{l}\text { Upper side of } \\
\text { the bladder } \\
\text { located along } \\
\text { the urachus }\end{array}$ & $\begin{array}{l}\mathrm{CT} \\
\mathrm{MRI}\end{array}$ & $\begin{array}{l}\text { Bladder } \\
\text { tumor } \\
\text { without } \\
\text { distant } \\
\text { metastasis }\end{array}$ & $\begin{array}{l}\text { Laparoscopic partial } \\
\text { cystectomy and } \\
\text { urachus removal }\end{array}$ & $\begin{array}{l}9 \text { months } \\
\text { without } \\
\text { recurrence }\end{array}$ \\
\hline $\begin{array}{l}\text { Mitchell } \\
\text { et al. } \\
2019\end{array}$ & $64 / M$ & $\begin{array}{l}\text { Recurrence } \\
\text { of bladder } \\
\text { leiomyomaafter } \\
\text { TUR-B, } \\
\text { History of } \\
\text { testicular } \\
\text { teratoma }\end{array}$ & $6 \mathrm{~cm}$ & $\begin{array}{l}\text { Postero-lateral } \\
\text { wall of the } \\
\text { bladder causing } \\
\text { obstruct-tion } \\
\text { of the left } \\
\text { ureterovesical } \\
\text { junction. } \\
\text { Severe hydro- } \\
\text { nephrosis and } \\
\text { hydro-ureter }\end{array}$ & $\mathrm{CT}$ & $\begin{array}{l}\text { Metastasis } \\
\text { of testicular } \\
\text { teratoma }\end{array}$ & $\begin{array}{l}\text { Open radical } \\
\text { cystoprostatectomy }\end{array}$ & $\begin{array}{l}6 \text { months } \\
\text { without } \\
\text { recurrence after } \\
\text { radical surgery }\end{array}$ \\
\hline $\begin{array}{l}\text { Fridman } \\
\text { et al. } \\
2018\end{array}$ & $51 / F$ & $\begin{array}{l}\text { Heavy vaginal } \\
\text { bleeding, pelvic } \\
\text { pressure, bladder } \\
\text { incon-tinence, } \\
\text { dyspar-eunia }\end{array}$ & $5.5 \mathrm{~cm}$ & $\begin{array}{l}\text { Inferior of } \\
\text { bladder \& } \\
\text { superior anterior } \\
\text { wall of urethra }\end{array}$ & MRI & $\begin{array}{l}\text { Paraurethral } \\
\text { mass }\end{array}$ & $\begin{array}{l}\text { Open paraurethral } \\
\text { resection }\end{array}$ & N/A \\
\hline $\begin{array}{l}\text { Mavridis } \\
\text { et al. } \\
2020\end{array}$ & 28/M & $\begin{array}{l}\text { Asymp-tomatic, } \\
\text { History of solitary } \\
\text { fibrous tumor of } \\
\text { pleura }\end{array}$ & $3.7 \mathrm{~cm}$ & $\begin{array}{l}\text { Left bladder } \\
\text { wall }\end{array}$ & CT & $\begin{array}{l}\text { Metastasis of } \\
\text { pleural tumor }\end{array}$ & $\begin{array}{l}\text { Open retropubic } \\
\text { resection }\end{array}$ & N/A \\
\hline $\begin{array}{l}\text { Tobias- } \\
\text { Machado } \\
\text { et al. } \\
2020\end{array}$ & $25 / M$ & $\begin{array}{l}\text { Urinary } \\
\text { frequency, } \\
\text { urgency }\end{array}$ & $3 \times 2 \mathrm{~cm}$ & $\begin{array}{l}\text { Postero-lateral } \\
\text { bladder wall }\end{array}$ & $\begin{array}{l}\text { USG, } \\
\text { MRI }\end{array}$ & $\begin{array}{l}\text { Bladder } \\
\text { leiomyoma }\end{array}$ & $\begin{array}{l}\text { Robot-assisted } \\
\text { transvesical partial } \\
\text { cystectomy \& } \\
\text { placement of right } \\
\text { urethral stent }\end{array}$ & $N / A$ \\
\hline $\begin{array}{l}\text { Li et al. } \\
2019\end{array}$ & $\begin{array}{l}50.2 \\
(n=6) \\
F(n=5) \\
M(n=1)\end{array}$ & $\begin{array}{l}\text { Asymp-tomatic } \\
(n=3) \\
\text { Irritative }(n=2) \\
\text { Hematuria } \\
(n=1)\end{array}$ & $\begin{array}{l}\text { Mean: } \\
3.9 \mathrm{~cm}\end{array}$ & $\begin{array}{l}\text { Endo-vesical } \\
(n=3) \\
\text { Intramural }(n=3)\end{array}$ & $\begin{array}{l}\text { USG, } \\
\text { CT, } \\
\text { Cystoscopy }\end{array}$ & $\begin{array}{l}\text { Bladder } \\
\text { tumor }\end{array}$ & $\begin{array}{l}\text { Transurethral } \\
\text { enucleation }\end{array}$ & $\begin{array}{l}\text { Mean } 14.8 \\
\text { months } \\
\text { without } \\
\text { recurrence }\end{array}$ \\
\hline $\begin{array}{l}\text { Zachoval } \\
\text { et al. } \\
2018\end{array}$ & $32 / F$ & $\begin{array}{l}\text { Asymptomatic } \\
\text { pregnant woman }\end{array}$ & $5 \mathrm{~cm}$ & $\begin{array}{l}\text { Anterior wall of } \\
\text { the bladder }\end{array}$ & $\begin{array}{l}\text { USG, } \\
\text { MRI }\end{array}$ & $\begin{array}{l}\text { Bladder } \\
\text { leiomyoma }\end{array}$ & Open resection & $\begin{array}{l}1 \text { year without } \\
\text { recurrence }\end{array}$ \\
\hline $\begin{array}{l}\text { Delara et } \\
\text { al. } 2021\end{array}$ & $33 / F$ & $\begin{array}{l}\text { Abdominal pain, } \\
\text { urinary urgency, } \\
\text { frequency, heavy } \\
\text { menses }\end{array}$ & $2.0 \times 1.3 \times 1.7 \mathrm{~cm}$ & $\begin{array}{l}\text { The left } \\
\text { posterior } \\
\text { bladder wall } \\
\text { adjacent } \\
\text { to the left } \\
\text { ureterovesical } \\
\text { junction }\end{array}$ & $\begin{array}{l}\text { MRI, } \\
\text { cystourethroscopy }\end{array}$ & Bladder mass & TUR-B & N/A \\
\hline
\end{tabular}

TUR-B: Transurethral resection of the bladder; USG: Ultrasound; CT: Computed Tomography; MRI: Magnetic Resonance Imaging 
tumor, and may even be asymptomatic (Table 1). The data analysis in Table 2 shows that computed tomography (CT) is mostly used for diagnosis and transurethral resection of the bladder (TUR-B) is the common treatment method for endovesical-type bladder leiomyomas. Additionally, the mean size is 4.16 (range, 1.8-6.7) $\mathrm{cm}(n=16)$, and the mean follow up period is 11.5 (range, 2-30) months ( $n=11$ ) (Table 2). Here, we report a rare, giant, extravesical-type bladder leiomyoma. Our case is unique with its giant size $(15.5 \times 14.5 \times 14 \mathrm{~cm})$, its extension to the parametrium, which created confusion in diagnosis by mimicking a cervical tumor, and its ureter complications. Although recurrence had been reported in two cases previously, the present case showed no recurrence during cesarean sections.

Table 2: Analysis of case reports reported as bladder leiomyomas between 2016 and 2021

\begin{tabular}{|c|c|}
\hline Mean age & 42.81 \\
\hline Gender (n, \%) & F: $14,63.6 \% \mathrm{M}: 8,36.4 \%$ \\
\hline Mean size $(\mathrm{cm})$ & $4.04 \mathrm{~cm}(1.1$ to $6.7 \mathrm{~cm})$ \\
\hline Diagnostic tool & $\begin{array}{l}\text { CT }(n=15,68.2 \%), \text { USG ( } n=15 \text {, } \\
68.2 \%) \text { MRI }(n=6,30 \%) \text { Cystosco- } \\
\text { py }(n=11,5 \%) ; \text { Doppler USG ( } n=1 \text {, } \\
4.6 \%) ; \text { PET-CT }(n=1,4.6 \%)\end{array}$ \\
\hline
\end{tabular}

Treatment Open abdominal resection $(n=7$, $31.8 \%)$; TUR-B ( $n=13,59.1 \%)$; Robotic surgery ( $n=1,4.6 \%)$; Laparoscopic surgery $(n=1,4.6 \%)$

Mean follow up 11.5 months (2 to 30 months) period (months) $(n=14)$

$N / A(n=8)$

In three of them, recurrence was reported.

Differential diagnosis between cervical pathologies and extravesical bladder tumor is difficult, even with an examination and radiologic investigation. Also, benign conditions such as lipomas, hamartomas or nephrogenic adenoma and malignant conditions such as urothelial carcinoma, adenocarcinoma or metastatic cancer of the urinary tract should be considered. Ultrasound is the first tool for suspected bladder leiomyoma due to the characteristic image of the mass protruding into the bladder cavity, especially in endovesical-type tumors (3). A smooth, homogenous, and hypoechoic mass in the bladder wall is observed in an ultrasound. Blood flow of the mass can be evaluated using Doppler flow to assess the possibility of malignancy (6). CT is a good option to show hypoattenuating mass, to detect the location and relation of mass with surrounding structures, and to identify cystic and solid components. Contrast-enhanced CT images improve the differential diagnosis (5). MRI is superior to CT in distinguishing the mesenchymal component of leiomyomas and preservation of the muscle layer (19). On MRI, blad-

der leiomyoma is similar to uterine leiomyoma imaging features, which visualize at intermediate signal intensity on T1-weighted images and low signal on T2-weighted images. Multiphase dynamic MRI studies with gadolinium can demonstrate the enhancement pattern of the solid component. Cystoscopy can be used to take a biopsy and successfully diagnose endovesical bladder leiomyoma and other types that have intravesical protrusion (3). Ultrasound and cystoscopy are sufficient tools for diagnosing intravesical bladder leiomyoma, whereas MRI is generally used for extravesical-type tumors. Pathologic evaluation is the golden standard for diagnosis (3).

Since we could not completely exclude malignancy histopathologically, we chose laparotomic surgical excision to prevent possible spread and seeding of tumors. For endovesical-type bladder leiomyomas, transurethral resection is one of the primary options (3). Minimally invasive surgery, such as laparoscopic or robotic myomectomy, are suitable options for extravesical and intramural-type tumors (13). However, surgeons must keep in mind morcellator restrictions and patients should be informed about the risk of intraperitoneal myometrial cell spread (20). Injury of the ureter and bladder, and severe hemorrhage of pelvic organs can be seen as complications.

Histopathologic diagnosis is needed to rule out malignancy. Microscopically, bladder leiomyoma consists of smooth muscle cells with eosinophilic cytoplasms and cigar-shaped nuclei. The feature that distinguishes uterus and bladder leiomyoma from leiomyosarcoma is the absence of mitotic activity, cytologic atypia or necrosis (21). Immunohistochemically, bladder leiomyoma stains diffusely with smooth muscle actin, desmin, and vimentin, but not with cytokeratin and S100 protein (2).

\section{CONCLUSION}

We present a unique case of giant sized extravesical bladder leiomyoma with ureteral complications, and a long follow-up period. Despite the best clinical examination and radiologic imaging, it may be difficult to distinguish extravesical bladder leiomyoma. Although bladder leiomyomas are rarely seen tumors, surgeons should keep them in mind during the differential diagnosis of a pelvic mass. Appropriate surgery should be performed for the diagnosis and treatment.

Informed Consent: Written consent was obtained from the participants.

Peer Review: Externally peer-reviewed.

Author Contributions: Data Acquisition- S.A.T., H.S., T.T., A. C.I., Y.S.; Drafting Manuscript- S.A.T., H.S.; Critical Revision of Manuscript- T.T., A.C.I., Y.S.; Final Approval and AccountabilityS.A.T., H.S., T.T., A.C.I., Y.S. 
Conflict of Interest: Authors declared no conflict of interest.

Financial Disclosure: Authors declared no financial support.

Acknowledgement: We would like to thank David F. Chapman, $\mathrm{BSc}$, for editing the article.

Bilgilendirilmiş Onam: Katılımcılardan bilgilendirilmiş onam alınmıştır.

Hakem Değerlendirmesi: Dış bağımsız.

Yazar Katkıları: Veri Toplama- S.A.T., H.S., T.T., A.C.I., Y.S.; Yazı Taslağı- S.A.T., H.S.; İçeriğin Eleştirel İncelemesi- T.T., A.C.I., Y.S.; Son Onay ve Sorumluluk- S.A.T., H.S., T.T., A.C.I., Y.S.

Çıkar Çatışması: Yazarlar çıkar çatışması beyan etmemişlerdir.

Finansal Destek: Yazarlar finansal destek beyan etmemişlerdir.

Teşekkür: Makalenin Ingilizce düzeltmelerine yardımcı olan Sayın David Chapman'a teşekkür ederiz.

\section{REFERENCES}

1. He L, Li S, Zheng C, Wang C. Rare symptomatic bladder leiomyoma: case report and literature review. J Int Med Res 2018;46(4):1678-84. [CrossRef]

2. Park JW, Jeong BC, Seo SI, Jeon SS, Kwon GY, Lee HM. Leiomyoma of the urinary bladder: a series of nine cases and review of the literature. Urology 2010;76(6):1425-9. [CrossRef]

3. Li A, Zhang P, Zhang M, Yang T, Yue Y, Chen G, et al. Transurethral Enucleation of Bladder Leiomyoma: A Series of Six Cases and Review of the Literature. Urol Int 2019;102(1):102-8. [CrossRef]

4. Xin J, Lai HP, Lin SK, Zhang QQ, Shao CX, Jin L, et al. Bladder leiomyoma presenting as dyspareunia: Case report and literature review. Medicine (Baltimore) 2016;95(28):e3971. [CrossRef]

5. Sharma A, Vadi SK, Sood A, Kumar S, Mete UK, Parkhi $M$, et al. Bladder Leiomyoma: A Rare Differential and a Potential Pitfall in the Evaluation for a Bladder Mass in (18) F-Fluorodeoxyglucose-Positron Emission Tomography/ Computed Tomography. Indian J Nucl Med 2018;33(3):264-5.

6. Pramod SV, Safriadi F, Hernowo BS, Dwiyana RF, Ksatriapraja RA. A large bladder leiomyoma. Urol Case Rep 2020;32:101211. [CrossRef]

7. Mitchell K, Barnard J, Luchey A. Locally Recurrent Leiomyoma of the Bladder Refractory to Visually Complete Transurethral Resection: An Indication for Cystoprostatectomy. Case Rep Urol 2019;2019:1086575. [CrossRef]
8. Fridman D, Abeshouse M, Sankin A. Paraurethral Leiomyoma as an Incidental Finding in Patient with Fibroid Uterus. Case Rep Obstet Gynecol 2018;2018:7042960. [CrossRef]

9. Yucel C, Budak S, Kisa E, Celik O, Kozacioglu Z. The Rare Togetherness of Bladder Leiomyoma and Neurofibromatosis. Case Rep Urol 2018;2018:2302918. [CrossRef]

10. Sodo M, Spirito L, La Rocca R, Bracale U, Imbimbo C. Partial cystectomy in young male for a urachal tumor masquerading a bladder leiomyoma. Arch Ital Urol Androl 2019;91(1):51-2. [CrossRef]

11. Zachoval R, Dukatova K, Svabik K. Vaginal ultrasound for imaging of a urinary bladder mass and treatment of a large leiomyoma of the urinary bladder in pregnancy. Int Urogynecol J 2018;29(4):601-2. [CrossRef]

12. Mavridis C, Georgiadis G, Lagoudaki ED, Skamagkas I, Heretis I, Koutsopoulos AV, et al. Bladder Leiomyoma with Synchronous Solitary Fibrous Tumor of the Pleura. Case Rep Urol 2020;2020:3717506. [CrossRef]

13. Tobias-Machado M, Pazeto CL, Borges RC. Robot-assisted transvesical partial cystectomy for leiomyoma of bladder trigone. Int Braz J Urol 2020;46(2):300.

14. Delara R, Wasson M, Khan A. Bladder Leiomyoma. J Minim Invasive Gynecol. 2021 Jan 4: S1553-4650(21)00002-9. [CrossRef]

15. Mendes JE, Ferreira AV, Coelho SA, Gil C. Bladder leiomyoma. Urol Ann 2017;9(3):275-7. [CrossRef]

16. Dodia B, Mahajan A, Amlani D, Bathe S. Leiomyoma of Urinary Bladder in Middle-Aged Female. J Obstet Gynaecol India 2017;67(2):147-9. [CrossRef]

17. Jamshaid A, Arshad Z, Zaidi SZ. Leiomyoma of the urinary bladder. J Pac Med Assoc 2017;67(9):1447-9.

18. Haddad RG, Murshidi MM, Abu Shahin N, Murshidi MM. Leiomyoma of Urinary Bladder Presenting with Febrile Urinary Tract Infection: A Case Report. Int J Surg Case Rep 2016;27:180-2. [CrossRef]

19. Sun S, Bonaffini PA, Nougaret S, Fournier L, Dohan A, Chong J, et al. How to differentiate uterine leiomyosarcoma from leiomyoma with imaging. Diagn Interv Imaging 2019;100(10):619-34. [CrossRef]

20. Glaser LM, Friedman J, Tsai S, Chaudhari A, Milad M. Laparoscopic myomectomy and morcellation: A review of techniques, outcomes, and practice guidelines. Best Pract Res Clin Obstet Gynaecol 2018;46:99-112. [CrossRef]

21. Barlotta R, Edwards DC, McGreen B, Levy J, Xia G, Brennan $M$, et al. Incidental Asymptomatic Leiomyoma of the Urinary Bladder. Urology 2018;113:6-9. [CrossRef] 